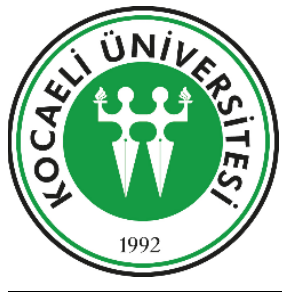

Kocaeli Üniversitesi Sağlık Bilimleri Dergisi

Letter to the Editor / Editöre Mektup

http://dergipark.gov.tr/kusbed

\title{
DETECTION OF HEMOGLOBIN D IN A PATIENT WITH HEMOLYSIS DUE TO DAPSONE TREATMENT
}

\section{DAPSON TEDAVISINE BA ĞLI HEMOLIZZ GÖRÜLEN BIRR HASTADA HEMOGLOBİN D SAPTANMASI}

\author{
@(D)Mahammed Okuyucu ${ }^{1 *}$, (D)Memiş Hilmi Atay², (Dirşen Bilgici ${ }^{3}$
}

${ }^{1} 19$ May1s University, Faculty of Medicine, Department of Internal Medicine, Samsun, Turkey

${ }^{2} 19$ Mayıs University, Faculty of Medicine, Department of Internal Medicine, Division of Hematology, Samsun, Turkey

${ }^{3} 19$ Mayis University, Faculty of Biochemistry, Department of Internal Medicine, Samsun, Turkey

ORCID iD: Muhammed Okuyucu: 0000-0002-6026-2024; Memis Hilmi Atay: 0000-0001-9666-6955; Birşen Bilgici: 0000-0001-7783-5039

*Corresponding Author / Sorumlu Yazar: Muhammed Okuyucu, e-mail / e-posta: muhammedokuyucu55@gmail.com

Received / Geliş Tarihi: 01.06.2019

Accepted / Kabul Tarihi: 29.07.2019

Published / Yaymm Tarihi: 06.09.2019

\section{Letter to the Editor}

\section{Detection of Hemoglobin D in a Patient with Hemolysis due to Dapsone Treatment}

Dear Editor,

Several mutations occur in the genes that encode globin chains which are a part of hemoglobin $(\mathrm{Hb})$ structure. Such mutations give rise to formation of different hemoglobin variants. ${ }^{1}$ One of these hemoglobin variants ( $\mathrm{Hb} \mathrm{C}, \mathrm{D}, \mathrm{E}, \mathrm{F}$ and $\mathrm{S})$ is $\mathrm{Hb} \mathrm{D}[\beta$ $121 \mathrm{Glu} \rightarrow \mathrm{Gln}(\mathrm{GAA} \rightarrow \mathrm{CAA})]$. Hb D occurs in $0.2 \%$ in Turkey. ${ }^{2}$ Molecular analysis has revealed many types of $\mathrm{Hb} \mathrm{D}$. $\mathrm{Hb}$ D-Los Angeles or Hb D-Punjab is the most common type. ${ }^{3}$ Clinically, heterozygous types of $\mathrm{Hb} \mathrm{D}$ do not produce any hematological manifestations. However, mild-to-moderate cases of hemolysis have been rarely reported in conjunction with its homozygous forms. ${ }^{4}$ In this study, we present a case of hemolysis due to dapsone theraphy in coexistence with $\mathrm{Hb} \mathrm{D}$. A 17-year-old female patient who had been on colchicin treatment for Behçet's disease for the last 3 years presented to the rheumatology department with persistent painful sores in her mouth. Following assessment of the patient, treatment with dapsone $50 \mathrm{mg}$ tablets, three times daily was started by the rheumatology department. Two months after initiation of medical treatment, the patient presented to the hematology department with complaints of pallor, chills and fatigue. Her diagnostic work-up showed the following: $\mathrm{Hb}: 11.2 \mathrm{~g} / \mathrm{dL}$ (11.9-14.6), MCV: 92.8 fL (81.8-95.5), PLT: 307 x 103/uL (173-390), reticulocyte count: $264.5 \times 10^{3} / \mathrm{uL}$ (17-63.8), reticulocyte\%: 7.09\%, LDH: $367 \mathrm{U} / \mathrm{L}(0-279)$, total bilirubin: $2.7 \mathrm{mg} / \mathrm{dL}$ (0.1-1.5), indirect bilirubin: $1.5 \mathrm{mg} / \mathrm{dL}(0.08-1.1)$ and haptoglobulin $<30 \mathrm{mg} / \mathrm{dL}$ (30-200). Peripheral smear showed the presence of spherocytes and fragmented red blood cells. Direct and indirect coombs tests were negative. Papain antibody and glucose 6 phosphate dehydrogenase (G6PD) tests were negative. Her laboratory values before dapsone therapy were as follows: $\mathrm{Hb}: 14.2$
g/dL, MCV: 85.2 fL, PLT: 309 x 103/uL. Initially, hemolytic anemia induced by dapsone was considered as possible diagnosis and dapsone treatment was discontinued. Laboratory work-up after three weeks showed a reticulocyte count of $125.6 \times 10^{3} / \mathrm{uL}$, $\%$ reticulocyte of $3.49 \%$. These results prompted a request for hemoglobin electrophoresis based on a preliminary diagnosis of thalassemia. Hb D was found as $41.65 \%$ (Figure 1). Moleculer genetic test (DNA analysis) was found to be Hb D-Los Angeles [c.3646>C(p.E122Q)(p.Glu.122Gln)(Heterozygous)].

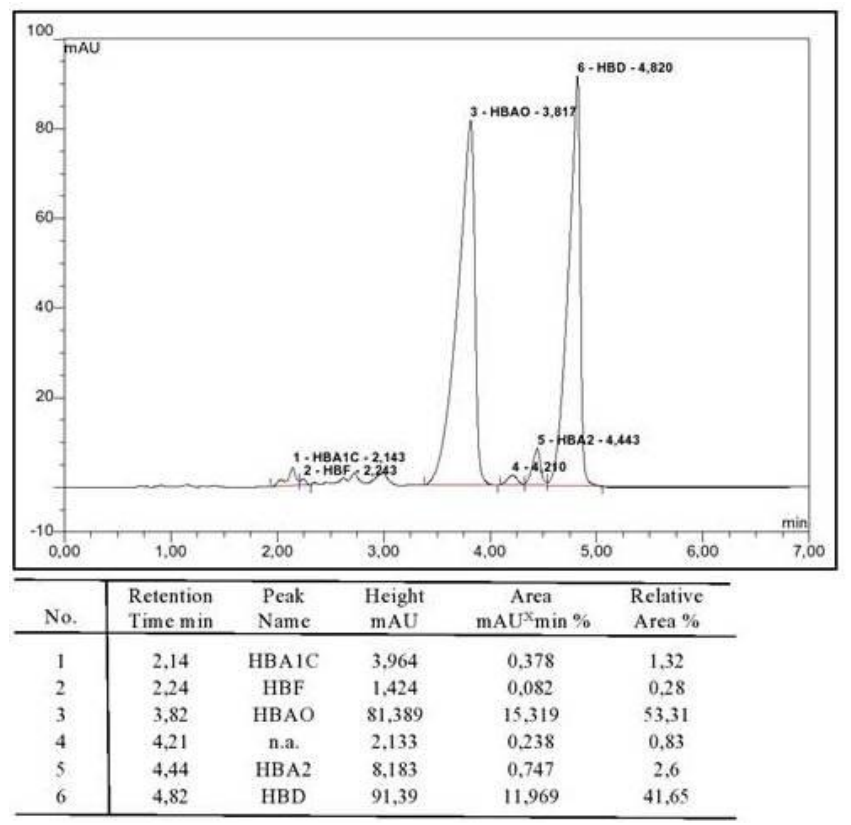

Figure 1. Patient's hemoglobin electrophoresis 


\section{References}

Hemoglobin electrophoresis was performed from the blood sample of her father and revealed $\mathrm{Hb} \mathrm{D}$ of $88.13 \%$ and $\mathrm{HbA} 2$ of $3.91 \%$. Her father was diagnosed with beta-thalassemia minor and $\mathrm{Hb} \mathrm{D}$.

Drugs are a rare cause of hemolytic anemia. Dapsone is known to cause oxidative hemolysis. This situation has been reported to result from the direct toxic effect of a hydroxlamine derivative formed by $\mathrm{N}$-hydroxylation to erythrocytes. ${ }^{5}$ Hemoglobin electrophoresis was performed for the patient during follow-up due to persistent hemolysis and a rare $\mathrm{Hb}$ variant was detected. This was a surprising finding for us, the physicians who were following the patient because her previous hemogram and biochemical analyses were not suggestive of thalassemia. Thus, we were facing two rare conditions at the same time: druginduced hemolysis and $\mathrm{Hb} \mathrm{D}$.

As a result; coexistence of hemolysis due to dapsone and $\mathrm{Hb}$ $\mathrm{D}$ is a rare condition. Since $\mathrm{Hb} \mathrm{D}$ was found to be heterozygous in the patient, we think that this condition did not have clinical effect on hemolysis. To the best of our knowledge, this is the first case in which $\mathrm{Hb} \mathrm{D}$ is detected in a patient with hemolysis due to dapsone.

Keywords: Hemoglobin D, dapson, hemolysis

\section{Acknowledgments}

None declared

\section{Conflict of Interest}

None declared

\section{Patient Consent}

Informed consent (via Journal of Health Sciences of Kocaeli University informed consent form) was obtained from the patient.

\section{Financial Disclosure}

None declared

\section{Author Contributions}

MO: evaluated the case and wrote the paper, MHA: evaluated the case and made critical review, BB: evaluated the case and made critical review.
1. Kohne E. Hemoglobinopathies: clinical manifestations, diagnosis, and treatment. Dtsch Arztebl Int. 2011;108(3132):532-40. doi:10.3238/arztebl.2011.0532.

2. Torres Lde S, Okumura JV, Silva DG, Bonini-Domingos CR Hemoglobin D-Punjab: origin, distribution and laboratory diagnosis. Rev Bras Hematol Hemoter. 2015;37(2):120-126. doi:10.1016/j.bjhh.2015.02.007.

3. Baglioni C. Abnormal human hemoglobins. VII. Chemical studies on hemoglobin D. Biochim Biophys Acta. 1962;59(2):437-449. doi:10.1016/0006-3002(62)90194-4

4. Taghavi Basmanj M, Karimipoor M, Amirian A, et al. Coinheritance of hemoglobin D and thalassemia traits in three families: clinical relevance. Arch Iran Med. 2011;14(1):61-63. doi:011141/AIM.0014.

5. Coleman MD. Dapsone toxicity: some current perspectives. Gen Pharmacol. 1995;26:1461. doi:0306-3623(95)00029-1 